\title{
COOPERATION NETWORKS AND TRANSFORMATIONS IN THE FOOD PRODUCTION AND DISTRIBUTION SYSTEMS OF FAMILY FARMING IN THE NORTH COAST OF RIO GRANDE DO SUL, BRAZIL
}

\author{
Redes de Cooperação e Transformações nos Sistemas de Produção e Distribuição de Alimentos da \\ Agricultura Familiar no Litoral Norte do Rio Grande do Sul
}

\begin{abstract}
This article mobilizes the theoretical approaches of novelty production and collective actions to analyze the construction of innovative organizational strategies in the North Coast of Rio Grande do Sul, Brazil, focusing on the sociotechnical transformations triggered by them. Based on documentary and field research conducted between August 2013 and April 2016, through observant participation and semi-structured interviews with family farmers, social mediators and researchers, it was possible to identify the consolidation of a peculiar network of collective actions, involving several social actors in the management of new and relevant media, which transform conventional food production and distribution systems. Evidenced as a 'novelty' in emergency, this articulation of social actors is largely related to the precepts of sustainability, reciprocity, sharing of knowledge, heterogeneity and dynamism of social action. Such interrelated devices seem to indicate a change in the development dynamics in the rural area of the study region.
\end{abstract}

Monique Medeiros

Universidade Federal de Santa Catarina

mmedeiros@ymail.com

Ademir Antônio Cazella

Universidade Federal de Santa Catarina

aacazella@gmail.com

Recebido em:13/01/2016. Aprovado em: 15/09/2017.

Avaliado pelo sistema double blind review

Avaliador científico: Daniel Carvalho de Rezende

DOI: $10.21714 / 2238-68902017 v 19 n 3 p 149$

\section{RESUMO}

Este artigo mobiliza as abordagens teóricas de Produção de Novidades e de Dispositivos Coletivos para analisar a construção de estratégias organizacionais inovadoras no Litoral Norte do Rio Grande do Sul, com foco nas transformações sociotécnicas por elas desencadeadas. A partir de pesquisas documental e de campo realizada entre agosto de 2013 e abril de 2016, por meio da participação observante e entrevistas semiestruturadas com agricultores familiares, mediadores sociais e pesquisadores, foi possível identificar a consolidação de uma rede peculiar de dispositivos coletivos, que envolve diversos atores sociais na gestão de novos e relevantes meios, os quais transformam sistemas convencionais de produção e distribuição de alimentos. Evidenciada como uma 'novidade' em emergência, essa articulação de atores sociais está amplamente relacionada com preceitos da sustentabilidade, reciprocidade, compartilhamento de conhecimentos, heterogeneidade e dinamismo da ação social. Tais dispositivos inter-relacionados parecem indicar uma alteração na dinâmica de desenvolvimento no espaço rural na região de estudo.

Keywords: Collective Actions, Novelty Production, Rural Development.

Palavras-chave: Dispositivos Coletivos, Produção de Novidades, Desenvolvimento Rural.

\section{INTRODUCTION}

The socio-environmental crises, which currently affect agriculture and generate consequences for the Brazilian society as a whole, highlight the limited idea of modern technology linked to a development project that benefits a small part of the population (ALMEIDA, 2009). Although this modernization process has begun decades ago and has been constantly criticized both in relation to the generated results in the recent past and in the present as well as its influence on the future, it is still hegemonic in rural areas and continues to generate a series of socio-environmental impacts. The displacement of distinct production factors based on the local tradition and the obscuring of expressions and originalities built by the unique characteristics of each people and culture are notorious.

The standardization of science and technology resulting from the modernization processes led agriculture to disconnect from local social contexts, ecology, time and space, the production of products from specific local qualities, and the family as a principle of social 
organization (PLOEG, 1994). Although this disconnection process of the agriculture as a sociocultural practice has predominated in society, not all social groups remained uncritical o their effects. Many farmers resisted this process in different ways and, instead of experiencing it as a disintegration of their living worlds, transformed the new code of communication and rationality that was imposed to them. According to their needs and interests, they interrelated different materialities associated with modernity and tradition (ARCE; LONG, 2000).

The rethinking on the role of farmers, both in research and in practical experimentation, as well as in the creation of public policies, involves the understanding that their initiatives are relevant in the configuration of social and material space, since they provoke readjustments, recreations and transformations in rural areas. This daily work, which puts different wisdom and knowledge in 'interface situations" ${ }^{\text {, }}$ provokes the establishment of negotiation processes and adjustments of meanings, generating distinct knowledge resulting from accommodation between interests and points of view from the involved actors, whether social mediators, farmers or public managers.

The richness and dynamism of these processes creates a scenario where there are constant transformations of the rural space and the practices developed in there. Thus, it is expected that there are socio-technical conditions favorable to novelty production in agriculture. This key term was coined from the need to particularize or evidence 'innovative' phenomena underway in rural areas. A novelty can be understood as a modification or a break in existing routines, or a new practice or way of doing, presumably with potential to promote improvements in existing routines (PLOEG et al., 2004). Such modifications or breaks of routines do not only contemplate those related to the production process, being related to forms of production organization and to the creation and consolidation of social organizations and institutional arrangements.

With the purpose of analyzing the construction and articulation of innovative organizational strategies in the North Coast of Rio Grande do Sul, Brazil, this article interrelates the perspective of novelty production (PLOEG et al., 2004) with the collective action approach proposed by Mormont (1996). For Mormont (1996), it

${ }^{1}$ Interface situations are defined as critical intersection points among different systems, fields or social domains, in which there are tendencies to find discontinuities according to differences of values and interests (LONG; PLOEG, 1989). is possible to understand collective action as a form of social mobilization around an objective or a claim. Based on this theoretical perspective, the farmer's point of view, particularly the family farmer, is highlighted, as well as it is shown that each uncertainty, driving the constitution of these collective actions, may have different values depending on the related situation. These understandings allow us establishing analytical connections between the decisions of a farmer accepting a great uncertainty in an area and facing the possibility of meeting some security in other areas and therefore following innovative paths (MORMONT, 2014).

The two theoretical approaches were mobilized for the analysis of field information obtained from social mediators and farmers' families in daily activities, such as work in street markets, appointments and meetings, activities on crops and their relationship with researchers and public managers in the region ${ }^{2}$. These activities were developed in the first phase of the study, between August 2011 and August 2013, and in the second phase, between September 2013 and July 2016, respectively, as rural extensionist and researcher of one of the authors. The extensionist activity was carried out at the Associação Riograndense de Empreendimentos de Assistência Técnica e Extensão Rural/Associação Sulina de Crédito e Assistência Rural (EMATER/ASCAR - RS), institution from the official rural extension service of the State.

This information was generated through essentially qualitative methodological tools carried out in the municipalities of Três Forquilhas, Terra de Areia, Itati, Osório, Maquiné, Dom Pedro de Alcântara and Torres, located on the North Coast of Rio Grande do Sul, Brazil (Figure 1). These tools included documentary research, participant observation and 64 semi-structured interviews, from which 38 were directed to family farmers and 26 to social mediators working in the region.

Besides this introduction, this article is divided into four main sections: in the first, the discussion about the novelty production perspective is deepened and, in the second, the collective action approach is presented more detailed. In the third, the focus is on the family farmers experiences in the construction of cooperation networks. In the fourth and last one, the considerations on the articulation between the collective actions and innovative dynamics of region's rural development are elaborated.

${ }^{2}$ This field research is correlated to the doctoral dissertation of the first author from the Graduate program in agroecosystem of the Federal University of Santa Catarina, defended in September 2017. 


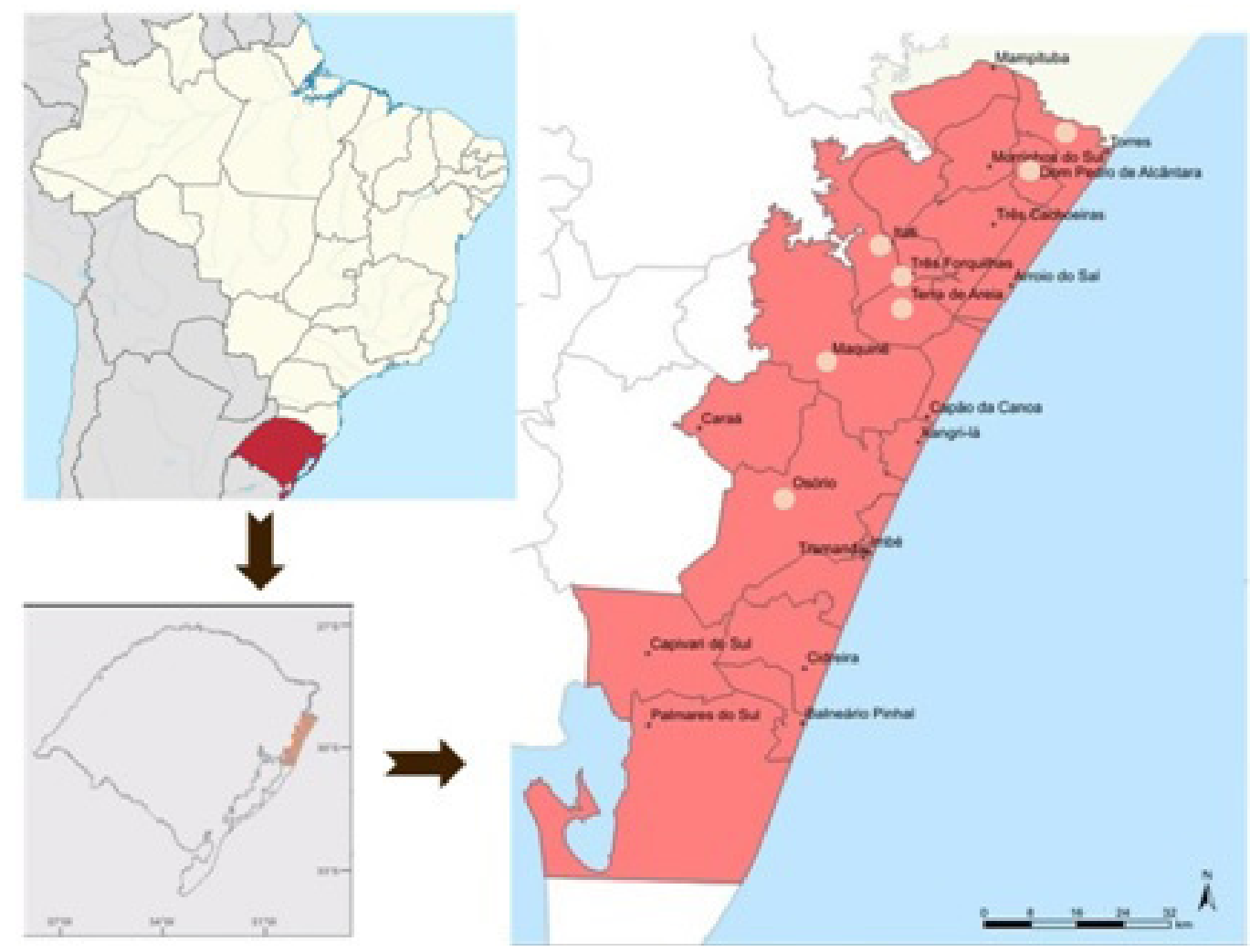

FIGURE 1 - Location of the North Coast region of Rio Grande do Sul and municipalities from the family farmers involved in the research. Adapted from: SPGG (2014)

\section{KNOWING THE NOVELTY: THE DYNAMICS OF ITS EMERGENCE}

The notion of novelty production seeks to highlight the complexity of the different agriculture styles and opposes the idea normally connected to factors as standardization, externalization and globalization of practices and artifacts. The novelties perform "breaks" and "disqualifications" in relation to the hegemonic logic of society and the institutional context (WISKERKE; PLOEG, 2004; OOSTENDIE; BROEKHUIZEN, 2008). On the other hand, the innovations, especially the far-reaching technological ones, seek the substitution of limiting inputs by artifacts manufactured by the industry and adapted to certain interests that aim to induce institutional changes, whose core is the capitalist accumulation (VENTURA; MILONE, 2004).

The novelty differentiation can be verified by three central points: i) the knowledge used for its construction is contextualized; ii) the practices involved in this construction are internalized or endogenous; and iii) the processes and artifacts created in these processes are territorialized (OOSTINDIE; BROEKHUIZEN, 2008). The first peculiarity is tied to the fact that the knowledge mobilized by social actors in the novelty production has a contextual character. It is constructed correlated to the socioeconomic, environmental, cultural and institutional context where the actors are inserted. After the interaction between the several types and sources of tacit and scientific knowledge in the novelty construction, new knowledge is constructed and then rooted in practices and epistemologies of these social actors (STUIVER, 2004; STUIVER, 2008).

The internalization of the novelty emergence, in turn, is related to the profitability and sustainability of novelties, since it involves the reduction of the use of external resources from the territory and from the production unit and hence the optimal use of internal resources (OOSTINDIE; BROEKHUIZEN, 2008; STUIVER, 2008). Thus, the novelties are born in a certain social and spatial site, resulting from a set of local social 
relationships and constructions performed in networks of social actors. The novelty emergence is therefore a territorialized process, dependent on the time, ecosystems and cultural repertoires to which the work processes are associated (WISKERKE; PLOEG, 2004). In this sense, territory is understood here other than a space delimited by peculiarities or similar production activities with established geographical borders, but as a result from actions of social actors seeking for resolution of shared problems (PECQUEUR, 2005; BONNAL; CAZELLA; DELGADO, 2011).

This set of characteristics leads to the finding that the radical character of novelties is evident in the possibility of breaking with productivist and purely economic patterns, which disconnect society from nature and devalue the cultural identity of social actors. Therefore, the novelties incite transformation processes that start from the micro level and can reach the macro. Accordingly, they are considered by Ploeg et al. (2004) as "transition seed" to a new paradigm of rural development.

The transformation processes resulting from the novelties are based on the reconnection of society with nature, through the agriculture development and the promotion of the co-production of interaction forms and reciprocal transformation of social and natural. In coproduction, the use of locally available natural resources allows recreating them, which occurs through dialectical articulation with the reconstruction and strengthening of sociocultural identities of actors involved in a cyclical system with natural resources (PLOEG, 2006; OOSTINDIE; BROEKHUIZEN, 2008). The reconnections driven by the novelties allow constructing new development projects, whose foundations are based on socioeconomic, cultural and environmental dimensions.

From the analysis of several studies aimed to investigate endogenous innovative processes in rural areas, which break the patterns and rules established by the dominant regime, Oostindie and Broekhuizen (2008) propose an analytical framework that identifies four distinct trajectories for the novelty emergence. The first refers to "resource improvement". In this trajectory, nature is constructed, reconstructed and differentiated within a long historical process, in which particularities emerge that show characteristics from the involved natural resources. In turn, as they result from coproduction processes, these resources are shaped and remodeled through the constant interaction between society and nature.
The second trajectory concerns the "fine tuning" between the farmer and an extensive list of growth factors ${ }^{3}$, which are continuously identified and corrected. Following the theory of limiting factors, the f growth factor that falls below the necessity limits the whole development process of a given agricultural activity in that locality. Therefore, the fine-tuning in the adjustment of these factors is often what promotes the novelty emergence. This is a dynamic process, since when correcting the original limiting factor, another one can arise in its place.

The third trajectory is associated with the "transposition of borders", i.e., the inclusion of new domains and activities by farmers. These activities may include food processing and marketing, as well as measures and strategies related to nature protection, among others. When these actions imply the expansion of intervention frontiers beyond production units, much more complex social organizations and networks may emerge. In this way, new experiences are translated into new knowledge that, in turn, inspire new practices.

The last trajectory refers to the "reordering of resource use". When addressing the connection of elements in an innovative way, such reordering is not restricted to the limits of the production unit nor to the agricultural activities stricto sensu. The novelty can arise from the interrelationship with elements belonging even to non-agricultural sectors. The trajectories associated with the novelty emergence do not necessarily occur linearly, one by one, in the presented order. They can be concomitant and follow a random order, since they are directly related to the decision-making of social actors in the specific situations of daily life.

These distinct trajectories are an inherent part of the development of certain agriculture styles, especially those linked to family farming. The search for autonomy from family farming segments ends up guiding the planning and operationalization of a heterogeneous rural development project, which is strengthened in the tangle of organizational processes that merge different social agency forms ${ }^{4}$.

${ }^{3}$ Growth factor for agriculture means the set of determining characteristics of limitations and potentialities from agricultural production processes. Examples include the inclusion of nutrients in the soil composition, the absorption capacity of these nutrients by the roots of plants and the water availability in the soil over time (OOSTINDIE; BROEKHUIZEN, 2008).

${ }^{4}$ One of the first authors to deal with this notion was the English sociologist Anthony Giddens (1989). For Giddens, the agency refers not to people's intentions to do certain things, but above all to their ability to put these things into practice. The agency depends on the individual's ability to generate changes in relation to a pre-existing state of affairs or course of events, which implies that all agents, even those in subordination positions, appropriate a particular type of power and can exert influences. 


\section{COLLECTIVE ACTIONS AS STRATEGIES TO OVERCOME ADVERSITIES}

According to Mormont (1996), there are three main areas of uncertainty that promote the construction of counter-hegemonic forms of cooperation by farmers: the ecological or technical-ecological, the economic, and the social or socio-political. The first one refers to the change of practices required in the technical-productive system in view of the new requirements of environmental protection and conservation, including regulated by specific environmental laws. Although there is currently consensus on the existence of pollution from agricultural sources, there are no precise ecological models which allow a given region assigning an exact pollution level to each agricultural practice. This situation is even more complex in contexts of high socioenvironmental diversity, as in the case of Brazil.

Faced with the scenario resulting from years of intense environmental impact, technical-ecological alternatives to avoid this impact are still imprecise for farmers. Although information has been facilitated in recent years by internet access or even the television media, some farmers find it difficult to access explanations in their local environment, especially regarding the limitations and cost-benefit of the implementation of a certain differentiated process in its production system. The need to adapt the production system to environmental legislation is often linked to the reduction of cultivated area and even to the transformation of the working way in agriculture. With this, farmers constantly seek the best productive use of the area based on techniques less harmful to the environment.

The second field is related to the doubt about the estimation of production cuts and yield losses. In this case, the uncertainty is built on the possible influence of the practical and technical changes in the economic strategy of development of the activity, organization of work and medium-term perspectives of farmers. In this way, the decisive factor for the farmer becomes the degree to which these changes will influence, in practice, his daily life.

The possible economic restrictions resulting from adherence to such adjustments should be viewed less as monetary as strategic. Although the proposed compensations are often exclusively monetary, such as the differentiation in the price of the produced food, it is possible that the farmer logic leads him to accept some new (and reversible) practices, not to be executed in its entire production unit, but only in specific plots. On the other hand, the logic of another farmer can lead him to adopt measures that suppose a complete reversal of the production system and hence demand bigger compensations (MORMONT, 1996).

Experiences involving farmers in the process of organic conversion, whose agricultural work system is transformed from a conventional model to an ecologically based model, illustrates this reflection. While some farmers initiate this process by applying new techniques in only part of their production unit, others opt for the change the entire production system. The first strategy highlights the need for farmers to test the potential of such changes over time, as well as to analyze the implications of these choices, then if they deem it important and/or interesting, to implement them later in their entire production area.

The second type of decision, among other factors, may be associated with the possibility of future economic gains, coming from the reach of a "premium price", which is defined as the price differential between the products coming from this production system and the conventional one (MEIRELES, 2003). The range of factors influencing farmers' reaction to the need for such changes is extensive. The farmer's age, the perspectives of family succession in the performed work, gender issues and access to technical assistance and participation in rural extension actions prepared by local institutions are only a few examples (STROPASOLAS, 2011).

The third field of uncertainty is sociopolitical and, according to Mormont (1996), to understand it, it must be considered that every decision made by the farmer implicitly includes a definition of his agricultural metier, his identity ${ }^{5}$ and the relational field in which such identity is recognized. Certain requirements for changing work practices do not correspond often to the farmer's professional identities, which, depending on how they are performed, can lead to uncertainty of identity maintenance and, in certain cases, to the redefinition of that identity.

These transformations refer to technical improvements in which there is a production that presents ecological and economic advantages. Although the reduction in the use of external resources in production is a catalyst factor for a less degrading agriculture, regarding the environment, the farmer needs specific knowledge to achieve this result. In order to meet this shortage, some specialized technical institutions maintain a productivist and significantly selective social contract with farmers. In other words, only farmers who fit the best of their technical work system will be involved in this search for innovation (MORMONT, 1996).

${ }^{5}$ Identity is understood here as a content, strongly expressed in discourses, as a field of relationships in which the individual is recognized for his abilities (MORMONT, 1996). 
This perspective differs substantially from the approach that conceives the farmer as an agent for nature, landscape and environment. It is assumed that the farmer has greater reflection abilities on the needs of sociotechnical transformations than an individual unfamiliar with the locality due to his knowledge on the environment, which may occur with the technicians who play the role of technical assistance and rural extension (MORMONT, 1996). For instance, if the farmer is a beekeeper, he will certainly know the detailed contribution of plant diversity to the maintenance of bees in the region and can therefore understand how urgent is the need to work with new agricultural practices that less damage the ecosystem.

Regarding this third area of uncertainty, the environment represents a specificity capable of being associated with certain agricultural products and that can be traded in short circuits or even receiving a regional identity seal. Thus, through the product and the relationship built with the markets, the farmer reconnects the environment to his agricultural activity. Each of these possible identity conformations - which are not incompatible with one another - presupposes social spaces of negotiation and adjustment in relation to specific demands.

\section{THE DYNAMICS OF RESOURCE REORDERING: FARMERS AND THEIR LIAISONS ON THE NORTH COAST OF RIO GRANDE DO SUL, BRAZIL}

In the North Coast of the State of Rio Grande do Sul, Brazil, situations regarding socioeconomic uncertainties were expressed due to the opportunities for commercialization of products from family farming are concentrated in the coastal municipalities of the region, which present an expressive flow of tourists in the summer, and in the metropolitan region of Porto Alegre, where is the Supply Center of Rio Grande do Sul (CEASA/RS).

In the coastal municipalities, the deliveries of these products are relevant in the commercial establishments located along the roads and even the sales at home. However, these marketing forms are restricted to the summer season, since tourists increase local consumption. However, the commercialization for CEASA/RS is even more significant due to the high quantity of products demanded in continuous flow. Nevertheless, for most of these farmers, commercialization at CEASA/RS depends on intermediaries who transport production to the points of sale and retain most of the profit made on sales.

Due to the uncertainty on their product destination and with technical support from whom, a collective of 27 family farmers from three municipalities in the region created in September 2006 the Mixed Cooperative of Family Farmers of Itati, Terra de Areia and Três Forquilhas (COOMAFITT). This collective action was created with the purpose of fostering new spaces for the exchange of information and facilitating access to different trade markets for the products from family farming.

Since then, this group has been strengthening and expanding, currently being composed of 208 farmers from the municipalities covered by the cooperative. The evolution of COOMAFITT is resulting particularly from its access to two public policies between 2008 and 2010 to support the so-called institutional markets: Food Acquisition Programme (Programa de Aquisição de Alimentos - PAA) and the Brazil's National School Lunch Program (Programa Nacional de Alimentação Escolar - PNAE) in 2010. Through the PAA, the purchased food is intended for people in situations of food and nutritional insecurity, those assisted by the social assistance network, and food and nutrition organizations (BRASIL/MDS, 2015). By PNAE, food purchased from family farmers is offered to students in public primary schools (BRASIL/FNDE, 2011).

Most importantly, these marketing channels, especially PNAE, were the most important consumer markets for the production sale for the current 201 families from cooperative farmers. It is worth noting that the scope of these initiatives is mediated by a variety of actors who act as animators and facilitators of rural development construction processes. This mediation is carried out more regularly and intensely by EMATER/ASCAR - RS and by two Non-Governmental Organizations (NGO), Ação Nascente Maquiné (ANAMA) ${ }^{6}$ and the Ecological Center ${ }^{7}$. The advisory actions of these organizations have shown to be significantly important to the paradigm changes of the region's family farming.

This mediation facilitated for cooperative managers to get in touch with other collective arrangements of family

\footnotetext{
${ }^{6}$ Founded in 1997, ANAMA concentrates its research and extension work in the municipality of Maquiné, RS, Brazil, and its surroundings. The NGO seeks to mediate between local reality and other institutional instances related to research, extension, community action, organized social movements and formulation of public policies, having as a guiding line the environmental issue allied to the valorization of cultural diversity. To this end, it counts on the partnership of different groups and local institutions, besides with financing mainly from the Federal Government (ANAMA, 2015).

${ }^{7}$ Created in 1985 in the municipality of Ipê, in the Serrana region of Rio Grande do Sul, the NGO arose with the aim of developing organic farming through projects and technical assistance together with families from ecological farmers. Currently, it develops projects financed by the Federal Government and international institutions, such as KFW, the German development bank, in two distinct regions of Rio Grande do Sul: the Serra and the North Coast (CENTRO ECOLÓGICO, 2010).
} 
farmers in order to enable the distribution of their products at different points of delivery. Therefore, through partnerships, especially with the Cooperative of Consumption and Commercialization of Small Rural Producers of the North Coast $^{8}$, the members of COOMAFITT have little by little built relationships that extend beyond the objectives of solving their logistics problems.

The contact with this collective action that, as well as COOMAFITT, also arose due to the need to overcome economic uncertainties of family farmers, favored the construction of ties among the members from different cooperatives, which resulted in meetings and technical visits among them. The exchange of technical and administrative information and the building of ties of trust favored by these moments made the COOMAFITT farmers to understand the importance of establishing alliances with other partners linked to the world of family farming.

In the North Coast, this knowledge interaction provided improvement for COOMAFITT partners on their agricultural practices and the gain in scale to meet the demand of the Conceição Hospital Group in the city of Porto Alegre ${ }^{9}$ and the restaurant of the Federal University of Santa Maria, through the institutional purchasing modality of the PAA. Besides these marketing channels, the cooperative provides food for three municipalities in the North Coast through the simultaneous donation of the PAA and for 15 other municipalities via PNAE.

Something similar happened with COOPVIVA, which currently comprises 53 members and started to supply products for the public sector of the municipality of São Leopoldo through the simultaneous donation of the PAA, and the Food Bank (note) of Porto Alegre. Moreover, public organizations in nine municipalities purchased food from their members through the PNAE. According to surveys conducted by the administrative sectors from both Cooperatives, their actions together currently benefit more than 65 thousand people via PAA and around 350 thousand by the PNAE.

${ }^{8}$ With headquarter in the municipality of Osório and constituted in 2010 by family farmers, COOPVIVA is directly advised by the extensionist agents of the EMATER offices located in the surrounding municipalities. Besides the host municipality, the cooperative covers five other municipalities: Maquiné, Caraá, Rolante, Santo Antônio da Patrulha, and Terra de Areia.

${ }^{9}$ The Conceição Hospital Group (Grupo Hospitalar Conceição - GHC) is composed by the hospitals Conceição, Criança Conceição, Cristo Redentor, and Fêmina, as well as a Emergency Care Unit, 12 health clinics of the Community Health Service, three psychosocial care centers and one Center for Technological Education and Health Research. Linked to the Ministry of Health, this structure forms the largest public network of hospitals in the South of the country, attending $100 \%$ through the National Health System (GRUPO HOSPITALAR CONCEIÇÃO, 2016).
The favorable results with the access to these public policies allowed the technical-ecological uncertainties, mainly regarding the change of production system from the conventional to the ecological ${ }^{10}$, were minimized for the members from both cooperatives. Since 2010, an informal group that gathered around six families of ecological farmers from the municipalities of Osório, Maquiné, Terra de Areia, Três Forquilhas and Itati, was supported and assisted by COOMAFITT in the search for new farmers interested in the conversion to ecologically based farming. With the support of rural extensionist agents of EMATER from these municipalities, the Cooperative invested in field, meetings and technical visits with its partners, environmental education work in schools of the region and, as a form of dissemination, participation in seminars, fairs and regional events. All these activities have turned to the importance of implementing a differentiated agriculture, respectful to the environment and valuing local knowledge, without losing sight of income generation for family farmers.

The group of ecological farmers grew and involved farmers, technicians and consumers in their transformation, first in an association and later in a participative conformity assessment body (Organismo Participativo de Avaliação da Conformidade - OPAC), the OPAC Litoral Norte. This body is accredited by the Ministry of agriculture, livestock and food supply (MAPA) and has the autonomy, guided by the Organic Law ${ }^{11}$, to certify the organic production ${ }^{12}$ of the group. The successful experiences resulted from this process joined some families from the municipalities of Dom Pedro de Alcântara and Torres to this collective action. The initial set consisting of six members became a collective action of 22 families, from which currently 12 have certified products. From these 12 families, seven are linked to COOMAFITT and two to COOPVIVA, and all provide their certified products to the institutional market.

\begin{abstract}
${ }^{10}$ Through technological adaptations that allow the sharing of local and introduced techniques, this production system differs from the conventional agriculture model because it does not make use of agrochemicals and is not dependent on nonrenewable natural resources. Practices linked to such a system range from respect for animal creations and concern not to generate waste, reusing as much material as possible from their activities, until the participation of farmers in collective actions.
\end{abstract}

${ }^{11}$ Article 2 of the Federal Law 10,831 provides as organic certification the act by which an accredited conformity assessment body gives written assurance that a clearly identified production or process has been methodically evaluated and is in conformity with the current organic production standards (BRASIL, 2007).

${ }^{12} \mathrm{Food}$ of plant or animal origin produced without the use of synthetic fertilizers, pesticides and transgenic. The cultural practices that base the production of these foods are aimed at establishing the ecological balance of the agricultural system (MAPA, 2015). 
This contact among organizations was so promising that the president of OPAC Litoral Norte, in 2013, became vice president of COOMAFITT, further strengthening relations among organizations.

By joining for disagreeing with the certification of organic products operated by commercial certifiers and opting for a differentiated form of access to the organic seal for their products, these farmers reinforce participatory certification. It is an alternative institutionality contrary to the conventional model of certification by auditing performed by private companies. This situation reiterates the importance of articulating these collective actions so that significant transformations occur in the conventional form of agricultural production (LONG; PLOEG, 1994).

The operation in the institutional market, besides opening spaces for commercialization, encouraged the production of differentiated foods and brought farmers closer to consumers. In the specific case of PNAE, farmers started to relate and negotiate directly with nutritionists and directors of municipal schools that receive their food. This proximity allowed Cooperatives not only understanding the demand for food in schools, but also to offer new products to compose school meals. For instance, in view of the need for baked goods in the institutional market, COOMAFITT decided to expand its network of partnerships.

Thus, the demand for these foods came to be attended by the Association of Women Farmers for Community Development of Três Forquilhas (AMADECOM). This collective action of women farmers linked to a rural family agro-industry ${ }^{13}$ of baked goods and native fruit pulp is accompanied by the NGO Centro Ecológico. The search for overcoming economic uncertainties, but especially of socio-political nature, allowed maintaining the collective identity of working women in the countryside.

Associated to COOMAFITT, the farmers of AMADECOM started delivering bread in 2012. The expansion of the supply of local products outside the North Coast of Rio Grande do Sul highlighted the importance of local raw materials for these families. As the main ingredient in the preparation of bread (wheat flour) is not cultivated in the region, the cassava, pumpkin and even

\footnotetext{
${ }^{13}$ Rural family agro-industry is understood as the form of organization in which the family produces, processes and/or transforms part of its agricultural and/or livestock production, aiming primarily its commercialization. This activity differs from food processing and raw material for self-consumption. While processing for self-consumption usually occurs in the kitchen of the farmer family, the family agroindustrialization takes place in a specific physical space, constituting a new socioeconomic enterprise (ESTEVAM; MIOR, 2014).
}

pulp of juçara palm fruits are now used as a differentiated raw material and of local origin ${ }^{14}$.

The connections among these collective actions also enabled the associates of COOMAFITT and OPAC Litoral Norte together with the City Hall of Capão da Canoa and the local EMATER, where the "Prove Capão" Fair was created at the end of 2011, a permanent space for family farming products. Thus, besides the institutional market, the organization has opened doors to the short marketing chains, which differ from the traditional market due to the proximity between producers and consumers. The "Prove Capão" Fair received the support of a parliamentary amendment and is currently held every Saturday in the municipality of Capão da Canoa, involving approximately 60 merchants that gradually see their incomes increase.

\section{FINAL CONSIDERATIONS: THE CONFIGURATION OF AN ORGANIZATIONAL INNOVATION IN THE FIELD}

The foundations of the articulation of these family farmers are based not only on economic aspects, but also on the social, political and institutional dimensions, in which social actors played a prominent role in the ongoing transformation. The interrelationship of agencies enabled the search for new forms of market access, the emergence of new production and organizational processes, and the definition of alternative institutions. These cooperation networks and their varied collective actions represent an emerging novelty.

The main reasons that lead us to consider the construction of these links between COOMAFITT, COOPVIVA, OPAC Litoral Norte and AMADECOM as a novelty are primarily because the creation of these networks has triggered a new relationship dynamic with the society. The production of food by family farmers in the institutional market and in short-chain markets implies a more direct contact in the marketing between farmer and consumer.

Secondly, this integration of social actors radiates, beyond the North Coast of Rio Grande do Sul, the idea and practice of a new relationship between society and nature, mainly through ecologically based agriculture developed by an increasing number of farmers in the region. A third reason refers to the fact that the social actors organized in

\footnotetext{
${ }^{14}$ The juçara palm (Euterpe edulis - Arecaceae) is a species originated from the Atlantic Forest, which occurs from the state of Rio Grande do Sul to Bahia. Besides the palm heart extracted from the inside of the petiole of its leaves, it produces a great quantity of fruits that, when ripe, has its pulp used for elaboration of varied dishes, from juices and ice creams to breads, pastas and sauces.
} 
these networks amplify processes of collective learning, either because the action facilitates actions of involved social mediators or because the dynamization of links increases the possibilities of exchanging a relevant 'know-how', breaking the isolation of many similar ongoing initiatives.

By identifying the limitations of the modernizing development model of agriculture as a problem, these farmers articulate themselves in the reduction of uncertainties and concurrently the meeting of strategies for the valorization of local resources. For this purpose, they perform observations and consecutive comparisons between the sociotechnical systems they had hitherto as references and their new strategies. After such reflections, a conciliation diagnosis is elaborated and the decisions are made about the ways that shall base the construction of new initiatives.

As the farmers increasingly approach the working logic with ecologically based agriculture, they are seek to adapt and improve their 'old' techniques and hence accumulate knowledge about localized forms of work, contributing to reconstruction of abilities that were in disuse or that were limited to the individual domestic scope. A kind of 'retro-innovation' can be recognized in the rescue of this knowledge, in its extensions and modifications, transfers to neighbors and work group members (STUIVER, 2006).

Retro-innovation is viewed as a transformative potential asset. Although based on networks of local actors, it changes the global-local dialectic through the new forms of established relationship. For instance, it depends on farmers who have global experiences, but who keep applying their ancestral experiences. These farmers are understood as key players by actively developing relevant concepts and practices that were forgotten, reintegrating agriculture into rural development (STUIVER, 2006).

In the North Coast of Rio Grande do Sul, these experiences of agriculture reconstruction as a social process, which are set in motion by the farmers involved in the different identified collective actions, are directly linked to the confrontation of the adversities arising from the advances of modern agriculture, and uncertainties in the economic, technical-ecological and sociopolitical fields. The option to recover from the past and adapt to the present several technical and productive forms of energy and capital saving have paved the way for the consolidation of new development forms, which assure an economic return to farmers and the maintenance of their identity as family farmers.

Although many of these initiatives were already performed prior to the creation of these cooperation networks, they have undergone improvements resulting from the mix of notions and experiences among social actors. Such initiatives include the use of shading ${ }^{15}$ in crops; the rotation of planted species in order not to deplete soil nutrients; the use of companion plants ${ }^{16}$ to optimize cultivation areas and plant quality; practices as the syrup preparation to control pests and diseases; organic compounds for the enrichment of soil fertility and biofertilizers ${ }^{17}$; and even the implementation of agroforestry systems, which combine tree, fruit and timber species with agricultural crops and/or animal husbandry.

In the empirical analysis of the research, the transformation of local productive practices enables the reflection and shared search by social actors for constant improvements in their work systems in agriculture. In these processes, permeated by experience exchanges and creation of links, new border transpositions are the possible for the farmers of the region. According to Oostindie and Broekhuizen (2008), these border transpositions can be compared to an 'immersion in the unknown'. In this immersion, new liaisons are generated and therefore new knowledges are needed. This applies not only to the creation of new activities and new networks that add income and employment opportunities in rural areas, but also to the construction of new responses to the changing needs and expectations of society.

Thus, these forms of border transposition are constantly created, recreated and adapted throughout the farmers' lives. The initiative of these actors in the operationalization of such connections is evidenced by the agency effectiveness, carried out through built social relationships, surpassing the individual capacity borders and establishing collective commitments (LONG, 2001).

The organizational transformations that are ongoing in the lives of the family farmers involved in the analyzed novelties can be identified as adaptations and reactions that, as part of their daily life, favor initiatives configured as deviations from the dominant sociotechnical regime. The regime, deeply rooted in the principles and processes of the agriculture modernization, is part of a development pattern understood as purely economic and technical.

\footnotetext{
${ }^{15}$ Interplanting of trees, especially those from the legume family, with some permanent crops. This practice aims to protect the commercial cultivation from the sunlight and hence to improve soil fertility.

${ }^{16}$ Companion plants are grown together to generate mutual benefits, stimulating their development and improving soil quality. Such 'companionship' occurs in a variety of ways, such as the shading of species and the exchange and release of nutrients and chemical compounds, such as stimulating hormones and repellents.

${ }^{17}$ The biofertilizer is a by-product generated by the biodigestion process of organic compounds that generally have a highnitrogen concentration and low carbon concentration. The use of biofertilizers helps to maintain the nutritional balance of plants, giving them greaterdefenseagainst pests and diseases without soil disruption, as occurs with the use of readily soluble fertilizers.
} 
Such deviations have led to new and alternative development processes in rural areas, in which the valuation of local knowledge and socio-environmental diversity is evidenced, generating re-arrangements in social and work relationships and the interaction between different knowledge, constituting learning processes, revitalizing reciprocity and trust links, as well as providing new meaning formations and reinvention of practices and techniques.

As we tried to demonstrate, it is possible to understand that access to PAA and PNAE, as well as the incentive of social mediation, enabled the structuring of articulations among collective actions, which provide a new dynamics of rural development in the region. The evolution of the COOMAFITT experience has influenced network members to challenge themselves and to broaden and diversify their production, to incorporate new family farmers, including ecologists and women, besides building new partnerships.

This expansion has generated more territorial processes of rural development and adapted to the local specificities, with incorporation of the environmental dimension. It is important to note that the leadership of the actors involved in the emergence of this novelty is related to the breaking of the rules established by the modernizing agricultural pattern and is inserted in broader processes occurring at a level of social action that extrapolates the local scale.

The experience accumulated by the different collective actions, now articulated in this cooperation network and in the concrete initiatives of access to the institutional market, is a fundamental ingredient so that government purchases can be consolidated as a tool capable of potentiating sustainable forms of food production and consumption in the region. These new forms of market and relationship with the government, which are only beginning to be undertaken, provoke new developments, opening spaces for other emergencies, such as the development of family agro-industries, which arise as the establishment of autonomous organizational forms of work, capable of adding value to primary production. Additionally, the OPAC, groups consolidated by reciprocity ties, which motivate several families to start, develop and remain in the practice of ecologically based agriculture.

\section{REFERENCES}

AÇÃO NASCENTE MAQUiNÉ. Diagnóstico socioeconômico e ambiental do município de Maquiné, RS: perspectiva para o desenvolvimento rural sustentável. Porto Alegre: Ed. UFRGS, 2000.
BRASIL. Lei $\mathrm{n}^{\circ}$ 6.323, de 27 de dezembro de 2007. Dispõe sobre a agricultura orgânica e dá outras providências. Diário Oficial [da] República Federativa do Brasil, Poder Executivo, Brasília, DF, 2007. Disponível em: $<$ http://www.planalto.gov.br/ccivil_03/ ato2007-2010/2007/decreto/d6323.htm > . Acesso em: $1 \overline{0}$ mar. 2015.

BRASIL. Ministério da Agricultura, Pecuária e Abastecimento. O que são alimentos orgânicos. Disponível em: <http://www.agricultura.gov.br/desenvolvimentosustentavel/organicos/o-que-e-agricultura-organica>. Acesso em: 7 nov. 2015.

BRASIL. Ministério do Desenvolvimento Social e Combate à Fome. Programa Bolsa Família. Disponível em: <http://www.mds.gov.br/bolsafamilia $>$. Acesso em: 15 dez. 2013.

\section{Programa de Aquisição de Alimentos}

(PAA). Disponível em: <http://www.mds.gov.br/ segurancaalimentar/decom/paa $>$. Acesso em: 18 out. 2011.

CARNEIRO, M. J. Agricultores familiares e pluriatividade: tipologias e políticas. In: COSTA, L. F. C.; BRUNO, R.; MOREIRA, R. J. (Org.). Mundo rural e tempo presente. Rio de Janeiro: Mauad, 1999. p. 323-344.

COTRIM, D. S.; GARCEZ, D.; MIGUEL, L. A. Litoral Norte do Rio Grande do Sul: sob a perspectiva de diferenciação e evolução dos sistemas agrários. 2007. Disponível em: <http://www.cnpat.embrapa.br/sbsp/ anais/Trab_Format_PDF/51.pdf $>$. Acesso em: 16 maio 2013.

FUNDO NACIONAL DE DESENVOLVIMENTO DA EDUCAÇÃO. Programa de Alimentação Escolar (PNAE): apresentação. Disponível em: <http:// www.fnde.gov.br/programas/alimentacao-escolar/ alimentacao-escolar-apresentacao>. Acesso em: 18 out. 2011.

GEELS, F. W.; SCHOT, J. Typology of sociotechnical transition pathways. Research Policy, Amsterdam, v. 36, n. 3, p. 399-417, 2007.

INSTITUTO BRASILEIRO DE GEOGRAFIA E ESTATÍSTICA. Censo demográfico: Brasil 2010. Rio de Janeiro, 2010. Disponível em: <http://www.ibge.gov. br>. Acesso em: 10 jul. 2013. 
LONG, N.; PLOEG, J. D. van der. Demythologizing planned intervention: an actor perspective. Sociologia Ruralis, Exeter, v. 29, n. 3/4, p. 226-249, Dec. 1989.

. Heterogeneity, actor and structure: towards a reconstitution of the concept of structure. In: BOOTH, D. (Ed.). Rethinking social development theory, research and practice. London: Longman Scientific \& Technical, 1994. p. 62-90.

LUZ, L. F. Agrobiodiversidade e agroindústria familiar rural: espaços de diálogo sobre os produtos da agricultura familiar no Litoral Norte do Rio Grande do Sul. 2012. 161 p. Dissertação (Mestrado em Desenvolvimento Rural)Faculdade de Ciências Econômicas, Universidade Federal do Rio Grande do Sul, Porto Alegre, 2012.

MARQUES, F. C. O nicho e novidade: nuanças de uma possível radicalização inovadora na agricultura. In: COLÓQUIO SOBRE AGRICULTURA FAMILIAR, 2., 2008, Porto Alegre. Anais... Porto Alegre: PGDR/ UFRGS, 2008. Disponível em: <http://www6.ufrgs.br/ pgdr/arquivos/ipode_53.doc $>$. Acesso em: 30 nov. 2010.

. Velhos conhecimentos, novos desenvolvimentos: transições no regime sociotécnico da agricultura: a produção de novidades entre agricultores produtores de plantas medicinais no Sul do Brasil. 2009. 220 p. Tese (Doutorado em Desenvolvimento Rural)-Faculdade de Ciências Econômicas, Universidade Federal do Rio Grande do Sul, Porto Alegre, 2009.

MIOR, L. C. et al. Redes e agroindústrias: as inovações organizacionais dos agricultores familiares e os novos mercados em Santa Catarina. In: CONGRESSO DA SOCIEDADE BRASILEIRA DE ECONOMIA, ADMINISTRAÇÃO E SOCIOLOGIA RURAL, 51., 2013, Belém. Anais Eletrônicos... Belém: SOBER, 2013. Disponível em: $<\mathrm{http}$ ://icongresso.itarget.com.br/useradm/ anais/?clt=ser.3 $>$. Acesso em: 14 jan. 2014.

MORMONT, M. Agriculture et environnement: pour une sociologie des dispositifs. Economie Rurale, Paris, n. 236, p. 28-36, 1996.
Le sociologue dans l'action collective face au risque. Développement Durable et Territories, Artois, 2014. Disponível em: <https://developpementdurable. revues.org/8235>. Acesso em: 10 mar. 2015.

OOSTINDIE, H.; BROEKHUIZEN, R. The dynamic of novelty production. In: PLOEG, J. D.; MARSDEN, T. (Ed.). Unfolding webs: the dynamics of regional rural development. Assen: Gorgum, 2008. p. 68-86.

PLOEG, J. D. van der et al. On regimes, novelties, niches and co-production. In: WISKERKE, J. S. C.; PLOEG, J. D. van der (Ed.). Seeds of transition: essays on novelty production, niches and regimes in agriculture. Assen: Royal van Gorcum, 2004. p. 1-30.

RIO GRANDE DO SUL. Secretaria de Planejamento, Governança e Gestão. Um atlas para pensar e entender o Rio Grande. Disponível em: $<$ http://www1.seplag.rs.gov. br/atlas/>. Acesso em: 12 fev. 2014.

ROVER, O. J. Agroecologia, mercados e inovações sociais: o caso da Rede Ecovida de Agroecologia. Ciências Sociais UNISINOS, São Leopoldo, v. 47, n. 1, p. 56-63, 2011.

SABOURIN, E. Camponeses do Brasil: entre a troca mercantil e a reciprocidade. Rio de Janeiro: Garamond, 2009. $336 \mathrm{p}$.

STROPASOLAS, V. L. Desenvolvimento rural para quem?: os desafios para a inclusão dos excluídos na ação extensionista. Grifos, Chapecó, n. 2021, p. 9-48, 2008.

STUIVER, M. Highlighting the retro side of innovation and its potential for regime change in agriculture. In: MURDOCH, J.; MARSDEN, T. (Ed.). Between the local and the global: confronting complexity in contemporary agri-food sector. Amsterdam: Elsevier, 2006. p. 147-175. (Research in Rural Sociology and Development, 12).

WANDERLEY, M. N. B. de. Raízes históricas do campesinato brasileiro. In: TEDESCO, J. C. (Org.). Agricultura familiar: realidades e perspectivas. 3. ed. Passo Fundo: EDIUPF, 2001. cap. 1, p. 21-55. 